\title{
Molecular investigation of tick-borne pathogens in ticks collected on migratory birds in Lithuania
}

\author{
Aušra Žèkienè ${ }^{1}$, \\ Algimantas Paulauskas ${ }^{1 \star}$, \\ Jana Radzijevskaja ${ }^{1}$, \\ Vytautas Jusys ${ }^{2}$ \\ ${ }^{1}$ Vytautas Magnus University, \\ Vileikos st. 8, Kaunas LT-44404, \\ Lithuania \\ ${ }^{2}$ Ventès Ragas, Kintai, \\ Šilutè district, LT-99361, \\ Lithuania
}

\begin{abstract}
Wild birds are increasingly considered to be important in the global dispersal of tickborne pathogens as they are capable of transporting infected ticks over large distances. To define the role of migrating birds as hosts and disseminators of infected ticks in Lithuania we analysed immature stage of ticks feeding on different passerine bird species. During autumn 2009 and 2010 we screened 3959 migrating birds at Ventès Ragas ornithological station and found $7.2 \%$ birds infested with ticks. The most infested bird species were Erithacus rubecula and Prunela modularis. We used PCR and sequence analyses for detection and identifying of pathogens in ticks collected from migrating birds. Forty eight tick pools (consisting of 487 Ixodes ricinus ticks) were screened for tick-borne pathogens. Borrelia spp. were detected in 9 tick pools, Babesia spp. in 6 tick pools and Anaplasma phagocytophilum in one tick pool. Three Borrelia species were identified: B. garinii, B. afzelii and B. miyamotoi. The results of the present study showed the pathway of introduction of B. miyamotoi in Lithuania and confirmed the impact of birds on spreading of non-native invasive pathogens in new areas. The present study is the first report of Babesia microti in Lithuania. We did not find tick-borne encephalitis virus (TBEV) in ticks collected from migrating birds. The bird species that carried the highest number of infected ticks were Parus major and Erithacus rubecula.
\end{abstract}

Key words: migratory birds, Ixodes ricinus, Borrelia spp., Babesia microti, Anaplasma phagocytophilum

\section{INTRODUCTION}

Ixodes ricinus tick is common and widespread in Lithuania [1-3]. This species acts as vector for a wide range of pathogens of humans and animals, including Borrelia spp., Babesia spp., Anaplasma spp., Ehrlichia spp., Rickettsia spp., Francisella tularensis, and arboviruses such as Louping ill virus (LIV) and tick-borne encephalitis virus (TBEV) $[4,5]$.

Ticks have very little mobility, but they may be transported over long distances by their vertebrate hosts during feeding, in particular, bird hosts may efficiently transport

*Corresponding author. E-mail: a.paulauskas@gmf.vdu.lt ticks across geographical barriers [6-9] and spread tickborne pathogens. Birds, especially ground-feeding species, are at risk of tick infestation and are considered important in the global dispersal of ticks and tick-borne pathogens through their migration within and between continents $[10,11]$. It is possible that migratory birds are involved in dispersing of infected ticks from Eastern and Central Europe to other countries where they could raise a public health risk.

The aim of our study was to collect ticks from migratory birds in Lithuania, to define species of birds involved in spreading of ticks and to examine those ticks for Borrelia burgdorferi sensu lato, Babesia spp., Anaplasma phagocytophilum and tick-borne encephalitis virus. 


\section{MATERIALS AND METHODS}

Birds were trapped in nets during regular ringing work at Ventès Ragas ornithological station in Lithuania $\left(55^{\circ} 34^{\prime} \mathrm{N}\right.$, $\left.21^{\circ} 19^{\prime} \mathrm{E}\right)$. Tick screening comprised rapid visual assessment for the presence of any ticks on bare body parts, especially around the eyes and beak of each bird. All ticks were removed with tweezers, placed separately into snaplid tubes with RNAlater (Ambion) and stored according to the manufacturer's instructions.

All collected ticks were identified as I. ricinus, pooled (10 nymphs per pool and 20 larvae per pool) and each tick pool was crushed with the tip of a glass rod in liquid nitrogen. RNA and DNA extraction was performed using TriPure Isolation reagent (Roche Diagnostics).

The presence of pathogen RNA and DNA was tested using polymerase chain reactions. Sequences of PCR primers and fragment lengths of amplicons are given in Table 1.

Detection of B. burgdorferi s. l. was performed using the FL6 and FL7 primers targeting conserved regions of fla gene [12]. The OspA gene located on the linear 49-kb plasmid was used as target in multiplex PCR for genotyping B. burgdorferi s. l. Genotyping of positive samples was done using genospecies-specific primers for B. burgdorferi sensu stricto (GI), B. afzelii (GIII) and B. garinii (GII) [13] and by direct sequencing of the $16 \mathrm{~S}(\mathrm{rrs} A)-23 \mathrm{~S}(\mathrm{rrlA})$ intergenic spacer (IGS), using the IGS1-F and IGS1-R primers for the first PCR and IGS2-F and IGS2-R primers for the nested PCR [14].

A. phagocytophilum DNA was detected amplifying a fragment of the $m s p 4$ gene using MAP4AP5 and MSP4AP3 primers for the first PCR and msp4f, msp4r primers for the nested PCR as previously described $[15,16]$.

For the detection of Babesia spp., a part of the 18S rRNA gene was amplified according to Casati [17] using BJ1 and $\mathrm{BN} 2$ primers.

For the detection of TBEV specific RNA, F-TBE 1, RTBE 1 primers and a probe (TBE-Probe-WT) of a quantitative real time RT-PCR protocol according to Schwaiger and Cassinoti [18] were used. According to this method $86 \mathrm{bp}$ fragment of 3' non-coding region of all 3 TBE viral subtypes is amplified.

PCR products of borrelial 16S-23S intergenic spacer and partial $18 \mathrm{~S}$ rRNA gene were bidirectionally sequenced using the ABI Prism 3130 genetic analyzer (Applied BioSystems, USA). The obtained sequences were edited using Mega 5.05 program and aligned with each other and with the previously published sequences in the GenBank using the ClustalW multiple alignment option. A phylogenetic tree was then constructed based on the sequence distance method using the Neighbor-Joining (NJ) algorithm of Mega 5.05 Software. Pairwise distances between the sequences were computed using the Kimura 2-parameter method. The obtained Borrelia and Babesia sequences were submitted to the GenBank.

Table 1. Sequences of $P C R$ primers and probe used in this study

\begin{tabular}{|c|c|c|c|}
\hline Pathogen & Primer & Sequence $\left(5^{\prime}-3^{\prime}\right)$ & $\begin{array}{l}\text { Fragment length } \\
\text { (bp) }\end{array}$ \\
\hline \multirow{2}{*}{ B. burgdorferi s. I. } & FL6 & TTCAGGGTCTCAAGCTTGCACT & \multirow{2}{*}{276} \\
\hline & FL7 & GCATTTTCAATTTTAGCAAGTGATG & \\
\hline \multirow{2}{*}{ B. burgdorferi s. s. } & \multirow{2}{*}{ Gl } & AACAAAGACGGCAAGTACGATCTAATT & \multirow{2}{*}{544} \\
\hline & & TTACAGTAATTGTTAAAGTTGAAGTGCC & \\
\hline \multirow{2}{*}{ B. garinii } & \multirow{2}{*}{ GII } & TGATAAAAACAACGGTTCTG GAAC & \multirow{2}{*}{345} \\
\hline & & GTAACTTTCAATGTTGTTTTGCCG & \\
\hline \multirow{2}{*}{ B. afzelii } & \multirow{2}{*}{ GIII } & TAAAGACAAAACATCAACAGATGAAATG & \multirow{2}{*}{189} \\
\hline & & TTCCAATGTTACTTTATCATTAGCTACTT & \\
\hline \multirow{4}{*}{ Borrelia spp. } & IGS1-F & GTATGTTTAGTGAGGGGGGTG & \multirow{4}{*}{$400-1000$} \\
\hline & IGS1-R & GGATCATAGCTCAGGTGGTTAG & \\
\hline & IGS2-F & AGGGGGGTGAAGTCGTAACAAG & \\
\hline & IGS2-R & GTCTGATAAACCTGAGGTCGGA & \\
\hline \multirow{4}{*}{ A. phagocytophilum } & MAP4AP5 & ATGAATTA-CAGAGAATTGCTTGTAGG & \multirow{2}{*}{849} \\
\hline & MSP4AP3 & TT-AATTGAAAGCAAATCTTGCTCCTATG & \\
\hline & msp4f & CTATTGGYGGNGCYAGAGT & \multirow{2}{*}{380} \\
\hline & msp4r & GTTCATCGAAAATTCCGTGGTA & \\
\hline \multirow{2}{*}{ Babesia spp. } & BJ1 & GTCTTGTAATTGGAATGATGG & \multirow{2}{*}{470} \\
\hline & BN2 & TAGTTTATGGTTAGGACTACG & \\
\hline \multirow{3}{*}{ TBEV } & F-TBE 1 & GGGCGGTTCTTGTTCTCC & \multirow{3}{*}{68} \\
\hline & R-TBE 1 & ACACATCACCTCCTTGTCAGACT & \\
\hline & TBE-Probe-WT & FAM-TGAGCCACCATCACCCAGACACA-BHQ1 & \\
\hline
\end{tabular}




\section{RESULTS AND DISCUSSION}

Prevalence and intensity of ticks on migrating birds A total of 3959 migrating passerine birds of 19 species were captured and examined for ticks at Ventes Ragas ornithological station in Lithuania during the autumn migrations in 2009 and 2010. Only I. ricinus ticks were found. A total of 297 (54\%) nymphs and 258 (46\%) larvae were collected, no adult ticks were found, confirming that subadult ticks predominate on birds [10]

From 287 infested passerine birds of 11 different bird species 555 immature I. ricinus ticks were collected, giving a prevalence of $7.2 \%$ (287 of 3959 birds), a relative intensity of $0.14 \%$ tick per bird ( 555 ticks per 3959 birds) and mean intensity 1.93 ticks per infested bird (555 ticks per 287 birds). The prevalence of infested birds was lower in 2009 autumn migration: 2\% (39 of 2102 birds) compared to 2010 autumn migration: $13 \%$ (248 of 1857 birds). The relative intensity of tick infestation and the mean intensity of tick infestation were also lower during 2009 autumn migration compared to 2010 autumn migration with 0.03 tick per bird (68 ticks per 2102 birds) and 0.26 tick per bird (487 ticks per 1857 birds), respectively and with 1.7 ticks per infested bird (68 ticks per 39 birds) and 2 ticks per infested bird ( 487 ticks per 248 birds), respectively. The bird species most infested by ticks were European Robin (Erithacus rubecula) and Dunnock (Prunela modularis) (Table 2).

Our results confirm the results of other scientists that birds are infested with fewer ticks in comparison with other hosts [19-21, 11]. In this study we found that the relative intensity of ticks on birds was 0.14 ticks per bird (555 ticks per 3959 birds), this is $\approx 99$ times less than that we found on rodents in Lithuania, where relative intensity of ticks was 13.92 (11 430 ticks per 821 rodent) [1]. Our finding supported the opinion of Comstedt et al. [11] that migratory bird contribution in hosting and disseminating ticks may be at least as important as that of other hosts because of their high number of migrating populations. Ventės Ragas ornithological station is located in Ventes Ragas peninsula on the eastern coast of Curonian Lagoon on the White SeaBaltic Sea migratory flyway. Millions of birds pass this place annually [22].

Tick-borne pathogens in ticks collected from migratory birds

Forty-eight tick pools consisting of 487 ticks (252 larvae and 235 nymphs) collected in autumn 2010 were screened for tick-borne pathogens.

B. burgdorferi s. 1. infections were found in 19\% tick pools (in nine tick pools consisting of 20 larvae and 63 nymphs). These pathogens were detected in ticks collected from Great Tit (Parus major), European Robin (E. rubecula), Winter Wren (Troglodytes troglodytes), Hawfinch (Coccothraustes coccothraustes) and Brambling (Fringilla montifringilla) bird species (Table 3).

We identified two Borrelia genospecies from B. burgdorferi s.l.group (Borrelia species that caused Lyme borreliosis): B. afzelii (in two pools of 20 nymphs) and B. garinii (in four tick pools consisting of 31 nymph). Sequencing of $470 \mathrm{bp}$ fragments of 16S-23S IGS and BLAST alignment confirmed the identification of B. miyamotoi in one tick pool consisting of 10 nymphs (Fig. 1). B. miyamotoi belongs to a relapsing fever group, which is a genetically and ecologically different group of borreliae. B. miyamotoi genospecies was previously isolated only in Japan from I. persulcatus ticks.

Table 2. Infestation of migratory birds by Ixodes ricinus ticks*

\begin{tabular}{|c|c|c|c|c|c|c|c|c|}
\hline \multirow[b]{2}{*}{ Bird species } & \multicolumn{4}{|c|}{2009 autumn } & \multicolumn{4}{|c|}{2010 autumn } \\
\hline & No. birds & $\begin{array}{l}\text { No. } \\
\text { ticks }\end{array}$ & $\begin{array}{l}\text { No. }(\%) \text { birds } \\
\text { infested }\end{array}$ & $\begin{array}{l}\text { Mean no. ticks } \\
\text { per infested } \\
\text { bird }\end{array}$ & $\begin{array}{l}\text { No. } \\
\text { birds }\end{array}$ & $\begin{array}{l}\text { No. } \\
\text { ticks }\end{array}$ & $\begin{array}{l}\text { No. }(\%) \text { birds } \\
\text { infested }\end{array}$ & $\begin{array}{c}\text { Mean no. ticks } \\
\text { per infested } \\
\text { bird }\end{array}$ \\
\hline Aegithalos caudatus & - & - & - & - & 533 & 8 & $8(1.5)$ & 1 \\
\hline $\begin{array}{l}\text { Coccothraustes } \\
\text { coccothraustes }\end{array}$ & - & - & - & - & 3 & 4 & $3(100)$ & 1.3 \\
\hline Troglodytes troglodytes & 37 & 1 & $1(2.7)$ & 1 & 103 & 29 & $20(19.4)$ & 1.5 \\
\hline Prunela modularis & 15 & 1 & $1(6.6)$ & 1 & 17 & 14 & $5(29.4)$ & 2.8 \\
\hline Erithacus rubecula & 435 & 46 & $21(4.8)$ & 2.2 & 261 & 223 & $92(35.2)$ & 2.4 \\
\hline Turdus merula & 1 & 3 & $1(100)$ & 1 & 1 & 13 & $1(100)$ & 13 \\
\hline Regulus regulus & 65 & 1 & $1(1.5)$ & 1 & 56 & 3 & $3(5.4)$ & 1 \\
\hline Parus montanus & - & - & - & - & 105 & 6 & $6(5.7)$ & 1 \\
\hline Parus caeruleus & 747 & 1 & $1(0.1)$ & 1 & 173 & 3 & $3(1.7)$ & 1 \\
\hline Parus major & 260 & 4 & $3(1.1)$ & 1.3 & 566 & 179 & 105 (18.6) & 1.7 \\
\hline Fringilla coelebs & 408 & 11 & $10(2.4)$ & 1.1 & 10 & 5 & $2(20)$ & 2.5 \\
\hline Total: & 1968 & 68 & $39(2)$ & 1.7 & 1828 & 487 & $248(13.6)$ & 2 \\
\hline
\end{tabular}

* Only bird species with at least one tick infested individual are included in the table 
Ta ble 3. Prevalence of Borrelia spp., Babesia spp. and Anaplasma phagocytophilum in bird-fed Ixodes ricinus ticks collected at Ventès Ragas ornithological station in autumn of 2010

\begin{tabular}{cccccc|c|c}
\hline \multirow{2}{*}{ Bird species } & \multicolumn{2}{c|}{ Borrelia species; positive tick pools (number of nymphs; larvae) } & \multirow{2}{*}{ Babesia spp. } & $\begin{array}{c}\text { A. phagocyto- } \\
\text { philum }\end{array}$ \\
\cline { 2 - 5 } & Borrelia spp. & B. afzelii & B. garinii & B. miyamotoi & 2 \\
\hline Parus major & $4(32 ; 0)$ & $1(10 ; 0)$ & $2(22 ; 0)$ & $1(10 ; 0)$ & $2(22 ; 0)$ & $1(10 ; 0)$ \\
\hline Parus caeruleus & - & - & - & - & - & - \\
\hline Erithacus rubecula & $2(10 ; 20)$ & $1(10 ; 0)$ & - & - & $4(10 ; 58)$ & - \\
\hline Troglodytes troglodytes & $1(2 ; 0)$ & - & - & - & - & - \\
\hline Prunella modularis & - & - & - & - & - & - \\
\hline $\begin{array}{c}\text { Coccothraustes } \\
\text { coccothraustes }\end{array}$ & $1(4 ; 0)$ & - & $1(4 ; 0)$ & - & - \\
\hline Fringilla montifringilla & $1(5 ; 0)$ & - & $1(5 ; 0)$ & - & - & - \\
\hline Total: & $9(53 ; 20)$ & $2(20 ; 0)$ & $4(31 ; 0)$ & $1(10 ; 0)$ & $6(32 ; 58)$ & $1(10 ; 0)$ \\
\hline
\end{tabular}

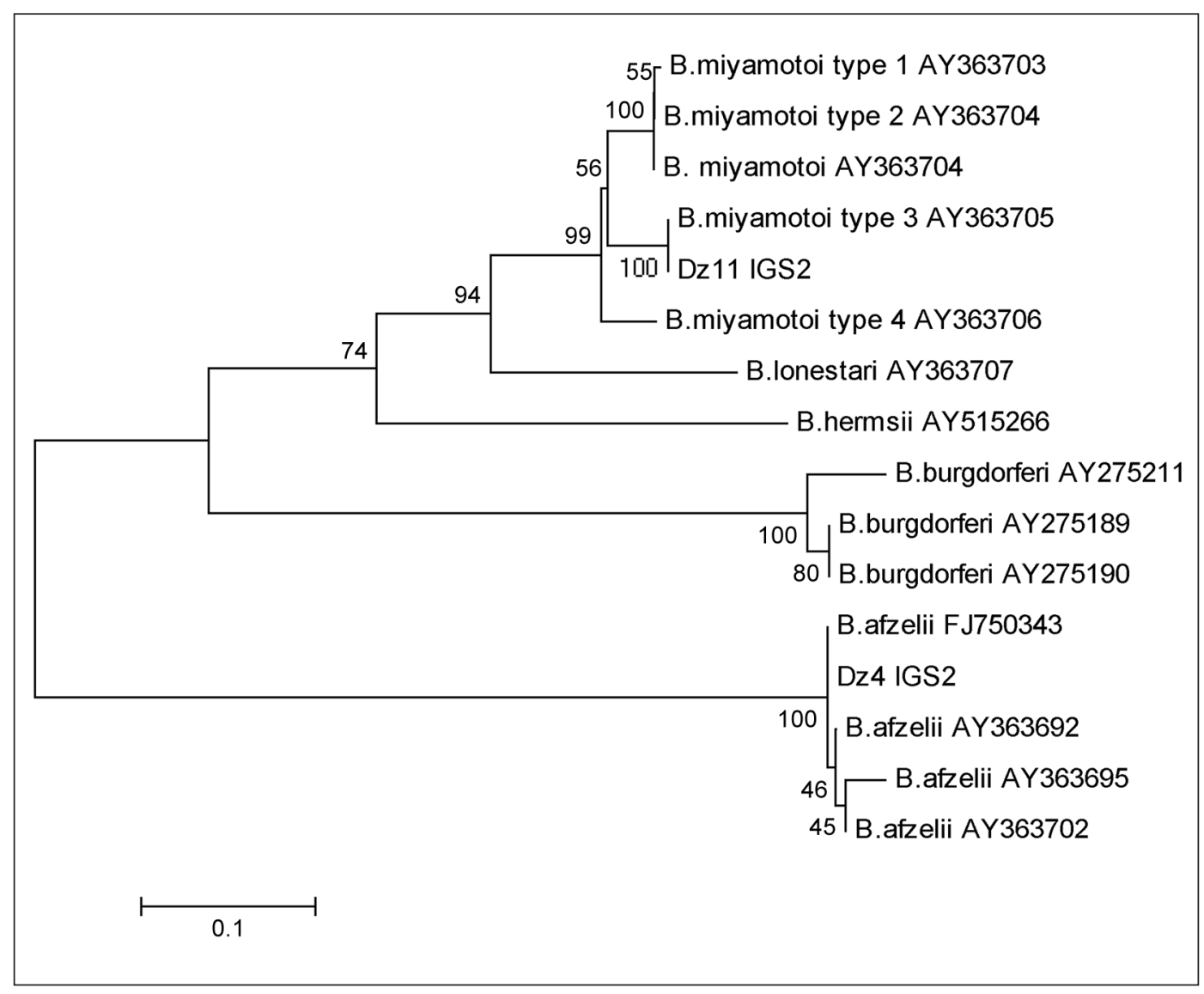

Fig. 1. Phylogenetic tree based on a comparison of 16S-23S ribosomal RNA gene intergenic spacer sequences of Borrelia species obtained by the Neighbor-Joining method and bootstrap analysis of 500 replicates. Strains with sequence accession number are given from the GenBank for comparison. Samples sequenced in the present study are indicated as Dz11 and Dz4. Abbreviations: Dz - ticks collected from Parus major. The scale bar indicates nucleotide substitutions per site

During the last two decades B. miyamotoi has been found at a low infection rate in I. persulcatus and I. ricinus [23-26] in Eurasia, and in I. scapularis and I. pacificus in North America $[14,27,26]$. In Europe, B. miyamotoi was first reported in Sweden in I. ricinus ticks. According to Ašoklienè [28], in Lithuania B. miyamotoi was detected in I. ricinus ticks collected from vegetation in 2005. The results of the present study showed the pathway of introduction of B. miyamotoi to Lithuania, and confirmed the impact of birds on spreading of non-native invasive pathogens in new areas. In the present study B. miyamotoi was detected in ticks feeding on Great Tit. 


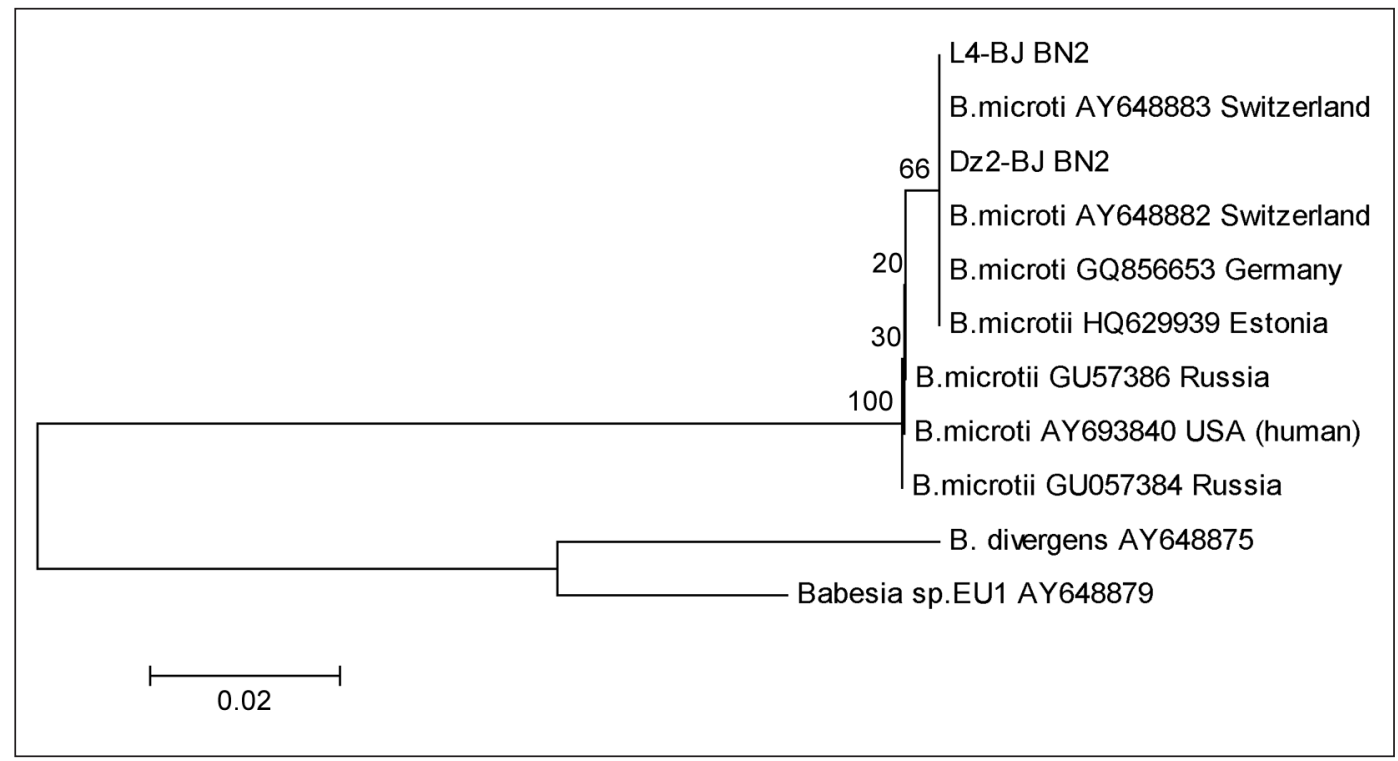

Fig. 2. Phylogenetic tree based on partial $185 \mathrm{r}$ RNA gene sequences of Babesia species. The phylogenetic tree was constructed using the Neighbor-Joining method and bootstrap analysis of 500 replicates.

The GenBank accession numbers for the sequences used in comparison are given. The Lithuanian sequences from the present study are indicated as Dz2 and L4. Abbreviations: $\mathrm{Dz}$ - ticks collected from Parus major; $\mathrm{L}$ - ticks collected from Erithacus rubecula

In 2 tick pools (consisting of 2 nymphs and 20 larvae) Borrelia genospecies were not identified.

The previous studies showed that in Lithuania about $13 \%$ of questing $I$. ricinus ticks are infected with $B$. burgdorferi $\mathrm{s}$. 1 . The most abundant genospecies in questing ticks is B. afzelii (9-76\%), followed by B. garinii (2.5-10\%) and B. burgdorferi s. s. $(0.4-7 \%)[12,1]$. In the present study B. garinii genospecies has been detected in four out of 9 positive tick pools collected from migratory birds. The low prevalence of B. afzelii in ticks collected from birds compared to host-seeking ticks may be explained by the observed differences in sensitivity to host serum among the B. burgdorferi s. l. strains. During feeding ticks take up hostderived molecules as complement and other blood components. It has been proposed that genospecies $B$. afzelii is sensitive to avian complement, and that these spirochetes are eliminated in the tick midgut, whereas $B$. garinii survives such a blood meal and can be transmitted to the host $[29,30]$.

Babesia spp. were detected in $13 \%$ of tick pools (in six tick pools consisting of 58 larvae and 32 nymphs) removed from P. major and E. rubecula species (Table 3). For identification of Babesia species, PCR products ( $470 \mathrm{bp}$ fragment of $18 S$ rRNR gene) of two positive pools were sequenced. Phylogenetic analysis indicated that sequences belonged to Babesia genus and were closely related to $B$. microti species (Fig. 2). The Lithuanian B. microti samples were found identical to the sequences previously found in
I. ricinus ticks in Switzerland, Belgium and Germany and slightly differed (by two nucleotide substitutions) from the strain belonging to the zoonotic "US" type, which has been reported as pathogenic for human [31] (Fig. 2). Previous studies in Lithuania showed that about 2-3\% of questing $I$. ricinus ticks harbored $B$. divergens $[12,32]$. The present study is the first report of Babesia microti in Lithuania.

A. phagocytophilum was found in one tick pool consisting of 10 nymphs removed from $P$. major (Table 3 ). A. phagocytophilum in questing I. ricinus ticks in Lithuania have an infection rate of $3-4 \%[12,32]$. The low prevalence of A. phagocytophilum in bird-fed ticks corresponds to previous investigations suggesting that birds have no reservoir competence for HGA agents [33].

TBE is an emerging disease in Lithuania [33], but we did not find TBE virus in ticks collected from migratory birds. TBEV has been isolated or serologically indicated from several bird species, especially anatids and gallinaceous birds, and most often from Eastern Europe or Russia [34]. In 2007 a Swedish group collected 1155 ticks from 447 (3.4\%) of 13260 screened birds and examined ticks for TBEV. Tick infestation with TBEV was low: they found TBEV in 2/529 larvae and 4/409 nymphs [35]. However, little is known about the capability of birds to function as reservoirs of TBEV, and small rodents remain the most important reservoirs of virus [35]. The role of birds in the epidemiology of TBE is still unknown. 


\section{CONCLUSION}

In the present study we detected Borrelia spp., Babesia spp. and Anaplasma phagocytophilum in ticks collected from migratory birds. Three Borrelia genospecies were identified: B. garinii, B. afzelii and B. miyamotoi. The results of the present study for the first time demonstrated the presence of B. microti in Ixodes ticks in Lithuania.

Infected ticks were carried by five bird species: $P$. major, E. rubecula, T. troglodytes, C. coccothraustes and F. montifringilla. The bird species that carried the highest number of ticks infected with different pathogens were P. major and E. rubecula. These avian species are ground-feeding which puts these birds at risk of tick infestation.

\section{ACKNOWLEDGEMENT}

This work was supported by the Research Council of Lithuania (grant No. MIP-071/2011).

Received 29 October 2011 Accepted 22 December 2011

\section{References}

1. Paulauskas A, Ambrasiene D, Radzijevskaja J, Rosef O, Turčinavičienė J. Diversity in prevalence and genospecies of Borrelia burgdorferi sensu lato in Ixodes ricinus ticks and rodents in Lithuania and Norway. Intern J Medic Microbiol 2008; 298(1): 180-7.

2. Paulauskas A, Radzijevskaja J, Turčinavičienè J, Ambrasiene D, Galdikaitė E. Data on some Ixodid tick species (Acari, Ixodidae) in the Baltic countries. New and rare for Lithuania insect species 2010; 22: 43-51.

3. Žygutienè M. Tick-borne pathogens and spread of Ixodes ricinus in Lithuania. EpiNorth 2009; 10(2): 63-71.

4. Estrada-Pena A, Jongejan F. Ticks feeding on humans: a review of records on human-biting Ixodoidea with special reference to pathogen transmission. Exp Appl Acarol 1999; 23: 685-715.

5. Brantsæter AB, Hoel T, Kristianslund TI, Mæland A. Tularemia after tick bite in Vestfold. Tidsskr Norske Laege 1998; 118: 1191-3.

6. Hoogstraal H, Kaiser MN, Traylor MA, Gaber S, Guindy E. Ticks (Ixodidea) on birds migrating from Africa to Europe and Asia. Bull World Health Organ 1961; 24: 197-212.

7. Poupon MA, Lommano E, Humair PF, Douet V, Rais O, Schaad M, Jenni L, Gern L. Prevalence of Borrelia burgdorferi sensu lato in ticks collected from migratory birds in Switzerland. Appl Environ Microbiol 2006; 72: 976-9.
8. Hasle G, Bjune GA, Edvardsen E, Jakobsen C, Linnehol BA, Røer JE, Mehl RA, Røed KH, Pedersen JE, Leinaas HP. Transport of ticks by migratory passerine birds to Norway. J Parasitol 2009; 95: 1342-51.

9. Hasle G, Horak IG, Grieve G, Leinaas HP, Clarke F. Ticks collected from birds in northern South Africa, 2004-2006. Onderstepoort J Vet 2009; 76: 167-75.

10. Olsen B, Jaenson TGT, Bergstrom S. Prevalence of Borrelia burgdorferi sensu lato-infected ticks on migrating birds. Appl Environ Microbiol 1995; 61(8): 3082-7.

11. Comstedt P, Bergstrom S, Olsen B, Garpmo U, Marjavaara L, Mejlon H, Barbour AG, Bunikis J. Migratory Passerine Birds as Reservoirs of Lyme Borreliosis in Europe. Emerg Infect Dis 2006; 12(7): 1087-95.

12. Ambrasiene D, Vascilo I, Jenkins A, Allum AG, Strand L, Kristiansen BE. The first study of identification of Borrelia, Ehrlichia and Babesia in Ixodes ricinus ticks from Lithuania using molecular methods. 2004; 14th European Congress of Clinical Microbiology and Infectious Diseases.

13. Demaerschalck I, Massaoud A, Kesel M, Hoyois B, Lobet Y, Hoet P, Bigaignon G, Bollen A, Godfroid E. Simultaneous presence of different Borrelia burgdorferi genospecies in biological fluids of Lyme disease patients. J Clin Microbiol 1995; 33: 602-8.

14. Bunikis J, Garpmo U, Tsao J, Berglund J, Fish D, Barbour AG. Sequence typing reveals extensive strain diversity of the Lyme borreliosis agents Borrelia burgdorferi in North America and Borrelia afzelii in Europe. Microbiol 2004; 150(6): 1741-55.

15. De la Fuente J, Massung RF, Wong SJ et al. Sequence analysis of the msp4 gene of Anaplasma phagocytophilum strain. J Clin Microbiol 2005; 43(3): 1309-17.

16. Bown KJ, Lambin X, Ogden NH, Petrovec M, Shaw SE, Woldehiwet Z, Birtles RJ. High-resolution genetic fingerprinting of European strains of Anaplasma phagocytophilum by use of multilocus variable-number tandem-repeat analysis. J Clin Microbiol 2007; 45: 1771-6.

17. Casati S, Sager H, Gern L, Piffaretti JC. Presence of potentially pathogenic Babesia sp. for human in Ixodes ricinus in Switzerland. Ann Agric Environ Med 2006; 13: 65-70.

18. Schwaiger M, Cassinotti P. Development of a quantitative real-time rt-PCR assay with internal control for the laboratory detection of tick borne encephalitis virus (TBEV) RNA. J Clin Virol 2003; 27: 136-45.

19. Hanincova K, Taragelova V, Koci J, Schafer SM, Hails R, Ukllmann AJ et al. Association of Borrelia garinii and B. valaisiana with songbirds in Slovakia. Appl Environ Microbiol 2003; 69: 2825-30.

20. Slowik TJ, Lane RS. Birds and their ticks in northwestern California: minimal contribution to Borrelia burgdorferi enzootiology. J Parasitol 2001; 87: 755-61. 
21. Eisen L, Eisen RJ, Lane RS. The roles of birds, lizards, and rodents as hosts for the western black-legged tick Ixodes pacificus. J Vector Ecol 2004; 29: 295-308.

22. Patapavicius R. An overview of birds ringing in Lithuania during 75 years (1929-2003). In: Grigonis R, Oranskyte I (eds.). Kaunas zoological museum of Tadas Ivanauskas 2006; 1: 98-101.

23. Fraenkel CJ, Garpmo U, Berglund J. Determination of novel Borrelia genospecies in Swedish Ixodes ricinus ticks. J Clin Microbiol 2002; 40(9): 3308-12.

24. Richter D, Schlee DB, Matuschka FR. Relapsing feverlike spirochetes infecting European vector tick of Lyme disease agent. Emerg Infect Dis 2003; 9: 697-701.

25. Barbour AG, Bunikis J, Travinsky B, Hoen AG, DiukWasser MA, Fish D et al. Niche partitioning of Borrelia burgdorferi and Borrelia miyamotoi in the same tick vector and mammalian reservoir species. Am J Trop Med Hyg 2009; 81: 1120-31.

26. Platonov AE, Karan LS, Kolyasnikova NM, Makhneva NA, Toporkova MG, Maleev VV et al. Humans infected with relapsing fever spirochete Borrelia miyamotoi, Russia. Emerg Infect Dis 2011. http://dx.doi. org/10.3201/eid1710.101474

27. Mun J, Eisen RJ, Eisen L, Lane RS. Detection of a Borrelia miyamotoi sensu lato relapsing-fever group spirochete from Ixodes pacificus in California. J Med Entomol 2006; 43: 120-3.

28. Asokliene L. Laimo boreliozès epidemiologiniai dèsningumai Lietuvoje 1995-2006 metais. Daktaro disertacija. 2010. Vilnius.

29. Kurtenbach K, De Michelis S, Etti S, Schafer SM, Sewell HS, Brade V, Kraiczy P. Host association of Borrelia burgdorferi sensu lato - the key role of host complement. Trends Microbiol 2002; 10(2): 74-9.

30. Kjelland V, Stuen S, Skarpaas T, Slettan A. Borrelia burgdorferi sensu lato in Ixodes ricinus ticks collected from migratory birds in Southern Norway. Acta Vet Scandinavica 2010; 52: 59-63.

31. Gray J, Zintl A, Hildebrandt A, Hunfeld KP, Weiss L. Zoonotic babesiosis: Overview of the disease and novel aspects of pathogen identity. Ticks and Tick-borne Diseases 2010; 1: 3-10.

32. Radzijevskaja J, Paulauskas A, Rosef O. Prevalence of Anaplasma phagocytophilum and Babesia divergens in Ixodes ricinus ticks from Lithuania and Norway. Int J Med Microbiol 2008; 298 (Suppl .1): 218-21.

33. Skotarczak B, Rymaszewska A, Wodecka B, Sawczuk M, Adamska M, Maciejewska A. PCR detection of granulocytic Anaplasma and Babesia in Ixodes ricinus ticks and birds in west-central Poland. Ann Agric Environ Med 2006; 13: 21-3.
34. Hubálek Z. Pathogenic microorganisms associated with free-living birds (a review). Acta Sc Nat Brno 1994; 28: $1-74$.

35. Waldenström J, Lundkvist A, Falk KI, Garpmo U, Bergström S, Lindegren G, Sjöstedt A, Mejlon H, Fransson T, Haemig PD, Olsén B. Migrating Birds and Tickborne Encephalitis Virus. Emerg Infect Dis 2007; 13(8): 1215-8.

Aušra Žèkienè, Algimantas Paulauskas, Jana Radzijevskaja, Vytautas Jusys

\section{MIGRUOJANČIUS PAUKŠČIUS PARAZITUOJANČIŲ ERKIŲ IR JŲ PLATINAMŲ PATOGENŲ MOLEKULINIAI TYRIMAI LIETUVOJE}

\section{Santrauka}

Laukiniai paukščiai yra svarbūs erkių pernešamų patogenų platintojai tolimais atstumais. Norint išsiaiškinti migruojančių paukščių vaidmeni erkių pernešamų patogenų paplitimui Lietuvoje, buvo ištirtos nesubrendusios erkès, rastos ant įvairių žvirblinių paukščių. 2009 ir 2010 m. rudenị Ventès ornitologinëje stotyje patikrinus 3959 migruojančius paukščius nustatyta, kad 7,2 \% jų yra užsikrètę erkèmis. Labiausiai erkèmis užsikrètę buvo Erithacus rubecula ir Prunela modularis. Patogenai erkèse nustatyti DNR PGR ir sekoskaitos analizès metodais. Siekiant nustatyti, ar neužsikrètę erkių pernešamais patogenais, buvo patikrinti 48 erkių pulai (surinkti iš 487 Ixodes ricinus erkių). Borrelia spp. buvo nustatyta 9 , Babesia spp. - 6, o Anaplasma phagocytophilum - viename erkių pule. Iš jų buvo išskirtos trys Borrelia rūšys: B. garinii, B. afzelii ir B. miyamotoi. Mūsų tyrimai rodo, kad B. miyamotoi, kaip naujas invazinis patogenas, į Lietuvą gali patekti su migruojančiais paukščiais. Šio tyrimo metu Babesia microti Lietuvoje buvo nustatyta pirmą kartą. Erkèse, rastose ant rudenị migruojančių paukščių, neaptikta erkinio encefalito viruso. Daugiausiai patogenais užsikrètusių erkių rasta ant Parus major ir Erithacus rubecula.

Raktažodžiai: migruojantys paukščiai, Ixodes ricinus, Borrelia spp., Babesia microti, Anaplasma phagocytophilum 